\title{
The Importance of Value, Image, Credibility and Trust to Repurchase Intentions in Over-the-Counter Herbal Market in Sub-Saharan Africa
}

\author{
Peter Kwasi Oppong1, John Mensah ${ }^{2 *}$, Matilda Addae ${ }^{2}$ \\ ${ }^{1}$ Department of Entrepreneurship and Business Sciences, University of Energy and Natural Resources, Sunyani, Ghana \\ ${ }^{2}$ Department of Procurement and Supply Chain Management, Cape Coast Technical University, Cape Coast, Ghana \\ Email: peteroppong72@gmail.com, *jmjohnmensah@gmail.com, addaematilda@gmail.com
}

How to cite this paper: Oppong, P. K., Mensah, J., \& Addae, M. (2021). The Importance of Value, Image, Credibility and Trust to Repurchase Intentions in Overthe-Counter Herbal Market in Sub-Saharan Africa. Open Journal of Business and Management, 9, 2080-2099.

https://doi.org/10.4236/ojbm.2021.94110

Received: May 30, 2021

Accepted: July 27, 2021

Published: July 30, 2021

Copyright $\odot 2021$ by author(s) and Scientific Research Publishing Inc. This work is licensed under the Creative Commons Attribution International License (CC BY 4.0).

http://creativecommons.org/licenses/by/4.0/

\begin{abstract}
The significance of brand image, trust, credibility and perceived value to repurchase intentions has received considerable attention of late. However, few studies have investigated the impact of image, trust and credibility on repurchase intentions through the role of value as high-order construct, particularly in the over-the-counter herbal market. Hence, this study aims at exploring the impact of brand image, trust and credibility on value dimensions and in turn, their role in enriching repurchases intentions in the over-the-counter herbal market. Data were collected from a sample of 265 customers using a systematic sampling method. Structural equation modelling was used to test the hypotheses in the study. The study established that brand image, trust and credibility positively influence the value dimensions, which in turn, strengthen repurchase intentions. The study, therefore, recommends that managers should develop and harness image, trust, credibility and value dimensions to reinforce repurchase intentions in the over-the-counter herbal market.
\end{abstract}

\section{Keywords}

Brand Credibility, Image, Value, Repurchase Intentions, Herbal Medicine

\section{Introduction}

The use of plants for health and medicinal purposes for treating and managing diseases has been the primary traditional health system across the globe. Despite the broad use of modern medicines, the significant contribution of herbal medicines to basic health care delivery has gained popularity worldwide in re- 
cent years. WHO (1998: p. 6) defined herbal medicine as "plant-derived materials or products with therapeutic or other human health benefits which contain either raw or processed ingredients obtained from one or more plants". In high-income countries, nearly 80 percent of the population have used various forms of complementary and/or alternative medicines (CAM) in their lifetime (WHO, 2008). In the less developed countries, herbal medicines often represent the only important health care people can refer to. WHO (2011) reported that roughly more than half of the developing countries' population still depends on herbal therapies to satisfy their basic health needs. It has been emphasised that accessibility, availability, affordability and culturally acceptability of herbal medicines have accounted for their widespread use in developing countries (WHO, 1998).

Herbal medicine is often used to offer first-line and basic health service to people residing, particularly in rural or poorer communities where it is only available or affordable health care (ibid). Furthermore, close to half of Ghanaians continue to use herbal therapies for combating and managing their ailments (UNDP, 2007). With the ever-growing use of herbal medicine in the sub-Saharan Africa, particularly Ghana, the Food and Drugs Authority (FDA) and the Traditional Medicine Practice Council (TMPC) has been mandated to oversee its production and distribution. The herbal therapies are also bought as over-the-counter medications and often sold at pharmacies, over-the-counter (OTC) medicine stores and herbal stores. Over the years, there have been innovations in herbal medicinal products resulting from the introduction of modern machines and equipment for production and packaging in the sub-Saharan Africa. Currently, herbal medicines sold at retail stores are in the form of tablets, capsules, ointments, powders and liquids (Essegbey, Awuni, Essegbey, Akuffobea, \& Mica, 2014). The rapid increase in the number of traditional medicine firms established in the past few years has led to growing competition in the OTC market. This might have accounted for narrow product differences, leading to lower prices and hence, low profit. It has been noted that strong brand image, trust and credibility can engender increased perceived value, which in turn, supports customers' repurchase intentions (Baek \& King, 2011; Carnevale, Loureiro, \& Kabadayi, 2018; Pham \& Nguyen, 2019; Huang, Gao, \& Hsu, 2019). Enhanced customers' intentions to repurchase can create a platform to secure a large market share (Chaudhuri \& Holbrook, 2001), which may enable herbal medicine firms to gain higher profits to grow in the OTC market. The importance of brand image (Huang et al., 2019; Pham \& Nguyen, 2019), trust (Sirdeshmukh, Singh, \& Sabol, 2002; Carnevale et al., 2018), credibility (Baek \& King, 2011; Cuong, 2020), in supporting the formation of perceived value (De Toni, Eberle, Larentis, \& Milan, 2018; Huang et al., 2019), and in turn, its impact on repurchase intentions has been well-documented in the literature.

Moreover, a review of the literature shows that many authors have studied perceived value as a single construct (e.g., Zeithaml, 1988; Ryu, Han, \& Kim, 
2008; Cronin, Brady, \& Hutt, 2000; Chen \& Chen, 2010), and others as a multi-dimensional construct (e.g., Petrick, 2002; Kantamneni \& Coulson, 1996; Sweeney \& Soutar, 2001; Chuah, Marimuthu, \& Ramayah, 2014). However, authors who have examined perceived value as a multi-dimensional construct considered each dimension as a separate and independent construct (Chauh et al., 2014; Demirgüneş, 2015; Punniyamoorthy \& Raj, 2007), and few authors have evaluated the perceived value as a higher-order factorial model measuring the dimensions as a first-order construct. Hence, this study sought to examine how brand image, trust and credibility influence repurchase intentions through perceived value measuring the dimensions as first-order construct in the OTC herbal market. Therefore, this paper contributes to extending the prior studies on perceived value by demonstrating the essential role of image, trust and credibility in supporting repurchase intentions via the combined effect of perceived value dimensions in the OTC herbal market. The study also serves as a catalyst for managers to develop and harness brand image, trust, credibility and the value dimensions to reinforce repurchase intentions in the OTC herbal market within the sub-Saharan Africa.

\section{Theoretical Review and Research Hypotheses}

\subsection{Repurchase Intentions}

Customers' repurchase intentions have gained much attention from academia and practitioners in the last few years because of their critical role in enhancing a firm's survival in a competitive environment. Repurchase intentions have been identified in the literature as one of the customers' positive behavioural intentions (Rambocas, Kirpalani, \& Simms, 2018; Zeithaml, Berry, \& Parasuraman, 1996; Saha \& Theingi, 2009; Cronin et al., 2000). Repurchase intentions refer to individual consumers' decision to rebuy a specific service or product from the same supplier, despite the current and future circumstances (Hellier, Geursen, Carr, \& Richard, 2003). Alternatively, Oliver (2010: p. 15) viewed repurchase intentions as a "deeply held commitment to continue buying a brand in the future". The author further suggested that customers' repurchase intentions stem from recurring experiences of positive affect towards a brand. Zeithaml et al. (1996) noted that favourable intentions to repurchase a product or service from a company indicate that the customers are forging a firm relationship with a company. Hence, the intention to repurchase a brand is one of the several ways customers demonstrate a high level of loyalty. However, repeat purchase intention is also affected by several factors, including perceived quality (Zeithaml et al., 1996), satisfaction (Hellier et al., 2003), value (De Toni et al., 2018). Rambocas et al. (2018) also contended that customers are likely to engage in repurchase behaviour if they receive the best value from their purchases. Chaudhuri and Holbrook (2001) also noted that brand trust and affect contribute positively to repeat purchase intentions, which can lead to an increase in market share. 


\subsection{Brand Credibility}

Brand credibility is widely acknowledged as one of the most significant factors which facilitate consumer brand selection since it lowers purchasing decisions' uncertainty. Brand credibility measures the believability of a brand's product descriptions, which encourages consumers to assume that the brand has the ability and willingness to keep its promises consistently (Erdem \& Swait, 2004). The authors also noted that brand credibility entails trustworthiness and expertise. Trustworthiness is concerned with the consumers' perceptions of the firm's willingness to keep its promises, whilst expertise refers to its ability to follow through on the promise made. Keller (2013) also described brand credibility as the extent to which the brand is considered authentic. The brand's trustworthiness and expertise reflect the combined effect of past and present marketing campaigns and activities (Erdem \& Swait, 2004). Imperfect and asymmetric information structure in the market rooted in signalling theory from an information economics perspective creates uncertainty about product attributes, leading to a high search cost and perceived risk of buying decisions. Consequently, credible brands play a critical role in simplifying brand choice decisions by reducing information cost and perceived risks which may generate confidence in its product information (Erdem \& Swait, 1998). It has also been emphasised that credible brands increase the perceived quality and hence, the overall expected value of the brand. Empirical studies revealed that brand credibility contributes significantly to perceived value (Cuong, 2020; Baek \& King, 2011). Hence, the following hypothesis is postulated:

H1: Brand credibility is positively related to perceived value.

\subsection{Brand Trust}

The concept of trust has been studied in a variety of fields, including social psychology, sociology, management, and marketing, but there is no universally accepted definition. Morgan and Hunt (1994) pointed out that the concept of trust is based on confidence expectations and risk. According to the authors, trust refers to the belief that a relational party in exchange would not exploit the weakness of the other party. Thus, trust occurs when an individual has confidence in the reliability and integrity of the current relational party. In their view, the trusting party's confidence stems from the strong belief that the trustworthy party is reliable and has shown a high degree of integrity, which can be attributed to being consistent, competent, honest, fair, responsible, helpful, and benevolent.

Chaudhuri and Holbrook (2001) defined brand trust as the willingness of customers to rely on the ability of the brand to perform its intended purpose. The author further stated in a setting where consumers are more vulnerable due to high perceived risks, trust is critical. As a result, products that can be trusted are purchased more frequently and typically elicit a higher degree of attitudinal 
commitment because they are perceived to be reliable, safe, and genuine. YagueGuillen, Munuera-Alemán, and Delgado-Ballester (2003) also viewed brand trust as confident expectations about the reliability and intentions of the brand in a risky setting. The authors supported the view that risk is a key component of trust and that it can influence customers' choice and behaviour.

Following this definition, brand trust consists of reliability and intentions. Brand's reliability relates to its competence which is concerned with the perceptions that the brand fulfils its specified intent. Brand reliability is essential because it assures customers that the brand can reliably meet and exceed their expectations. This can foster positive brand attitudes and serve as the foundation for repeat purchases in a customer-brand relationship (Morgan \& Hunt, 1994). In contrast, brand intentions reflect the belief that the brand would protect the consumers' interests in the event of crisis. In other words, brand intention measures the understanding of a firm's behaviour that is characterized by good intentions toward the welfare and interests of its customers in the event of unforeseeable future risks (Yague-Guillen et al., 2003). Altruism, benevolence, integrity, dependability, and fairness are all aspects of brand trust. Studies show that brand trust has a positive impact on perceived value (Sirdeshmukh et al., 2002; Carnevale et al., 2018).

Hence, the following hypothesis is formulated:

H2: Brand trust is positively related to perceived value.

\subsection{Brand Image}

Brand image has long been known as a valuable brand asset that enhances a company's competitive position (Keller, 2013). Brand image, according to Keller (1993), refers to consumers' perceptions of a brand and is manifested in the associations that are stored in their minds. Brand association is described as anything associated with a brand that conveys the brand's meaning (Aaker, 1991; Keller, 1993). The brand association may take several different forms, but it typically refers to product-related or non-product characteristics.

However, an association is made up of brand attributes and/or benefits. Brand attributes represent those descriptive attributes that identify a product or service, whilst benefits reflect the perceptions of value and meaning that customers relate to the product attributes (Keller, 2013). A positive and distinct brand association provides differentiation, brand extensions, and a basis for buying decisions, processing, and recall of product information, and stimulating positive attitudes and feelings about a brand (Aaker, 1991).

The author further noted that brand image provides the basis for purchase decision and a source of customer satisfaction. Empirical studies also established that brand image has a direct effect on perceived value (Pham \& Nguyen, 2019; Lien, Wen, Huang, \& Wu, 2015; Huang et al., 2019).

Hence, the following hypothesis is posited: 


\section{H3: Brand image is positively related to perceived value.}

\subsection{Perceived Value}

In a highly competitive business environment, the high perceived value of a firm's offering plays a central role in influencing consumers' purchase intentions, which can provide an edge over the competition. Zeithaml (1988) defined perceived value as the customers' overall judgement of the product's utility relating to their expectations of what is obtained and what is provided. The author further indicated that perceived value is the difference between perceived benefits and sacrifice related to monetary and non-monetary costs. As a result, customer perceived value measures the trade-off between the benefits received from an offering and the costs of making different choices (Kotler \& Keller, 2012). Zeithaml (1988) suggested that customers interpret the value in terms of low price, whatever they want in a good or service, the quantity they get for the price paid, and what they get for what is offered.

A review of the literature indicates that some researchers have studied and operationalised perceived value as a single construct (e.g., Zeithaml, 1988; Ryu et al., 2008; Cronin et al., 2000; Chen \& Chen, 2010). According to Sánchez-Fernández and Iniesta-Benillo (2007), the single-dimensional study of perceived value is underpinned by the economic and cognitive-based utilitarian approach to conceptualising and measuring perceived value. Hence, perceived value has been described as the trade-off between functional performance and price (ibid).

However, other researchers have approached the concept as a multi-dimensional construct (e.g. Petrick, 2002; Kantamneni \& Coulson, 1996; Sweeney \& Soutar, 2001; Chuah et al., 2014). For example, research conducted by Sheth, Newman, and Gross (1991) focused on consumption value, explaining why consumers buy what they buy, and proposed five dimensions of consumption values that influence their choice behaviour. These include functional value, social value, emotional value, epistemic value and conditional value. Likewise, Kantamneni and Coulson (1996) suggested perceived core value, symbolic value, sensory value and commercial value are sources of perceived value. A study conducted by Sweeney and Soutar (2001) also proposed multiple dimensions of perceived value known as PERVAL, which can be used to evaluate customers' perceptions of the value of consumer durable goods at a brand level. The model consists of emotional value, social value, quality/performance, and price value. The authors defined quality/performance as the utility obtained from the perceived product quality and its expected performance. Emotional value relates to utility produced from the feelings or affective state of the product, whereas social value reflects the utility derived from the product's ability to improve social self-concept. Lastly, price value is concerned with the utility derived from the reduction of the product's perceived short and long term costs.

It has been emphasised that although the single-dimensional approach offers 
some advantage of simplicity, it ignores the complexity of consumers' perceptions of value such as the intrinsic, extrinsic and emotional benefits associated with a value (Sánchez-Fernández \& Iniesta-Benillo, 2007). Besides, Sweeney and Soutar (2001) argued that the multi-dimensional approach explains consumer choice better when assessing perceived value both quantitatively and qualitatively, than the single dimension approach. Moreover, the former produces better results when evaluating consumption value. In this regard, a multi-dimensional approach will be adopted to investigate the perceived value of herbal medicines in the OTC market. Furthermore, the study will rely on the Sweeney and Soutar (2001) PERVAL model to assess the perceived value of herbal medicines in the OTC market. Studies also show that perceived value directly influences repurchase intentions (De Toni et al., 2018; Huang et al., 2019). Consequently, the following hypothesis is posited:

H4: Perceived value is positively related to repurchase intentions.

\subsection{Conceptual Framework}

The conceptual framework explains narratively and diagrammatically the key constructs and their presumed relationships in the study (Miles, Huberman, \& Saldăna, 2014). Thus, in the present research, brand credibility, image and trust are predictor variables, perceived value is an intervening variable, whereas repurchase intention is an outcome variable. The framework presented in Figure 1 indicates that brand credibility, image and trust have a direct effect on perceived value, which in turn, is positively related to repurchase intentions. Here, brand credibility measures the degree of authenticity of the product information of a brand, indicating the ability and willingness of the brand to continuously deliver what has been promised (Erdem \& Swait, 2004), while brand image relates to the consumers' perceptions about a brand, consisting of favourable, unique and healthy associations registered in a consumer's mind (Keller, 1993). Perceived value also reflects customers' overall judgement of the product's utility based on the emotional, social, quality/performance and price value of the offering (Zeithaml, 1988; Sweeney \& Soutar, 2001). Moreover, trust measures the confident expectations about the reliability and intentions of the brand in an environment entailing risks to the consumer (Yague-Guillen et al., 2003). Likewise, repurchase intention shows the degree of individual consumers' decision to rebuy a

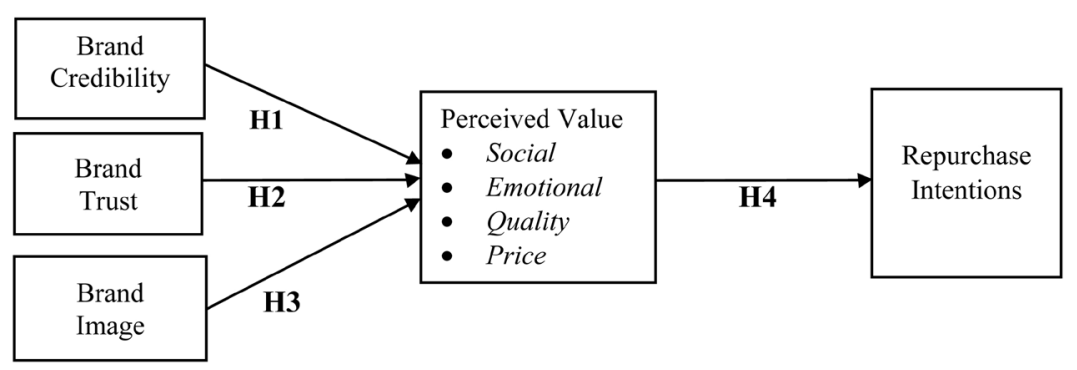

Figure 1. Conceptual framework. 
specific service or product from the same supplier, despite the current and future circumstances (Hellier et al., 2003).

\section{Research Methodology}

The research methodology used to achieve the goal of the study is outlined below:

\subsection{Study Population and Sample Size}

The study's population comprises made-in-Ghana herbal medicinal products, 26 herbal stores and 854 customers located in the Central Business District in the Cape Coast Metropolis. The number of the herbal retail outlets was obtained from TMPC, which is mandated to regulate their establishment, and that of the customers was from 26 herbal stores' daily sales data in the Cape Coast metropolis. A sample of 265 customers was selected, using Krejcie and Morgan's (1970) sample size framework.

\subsection{Scale Items of Development and Data Collection Method}

Multiple scale items with five-point responses ranging from $1=$ strongly disagree to $5=$ strongly agree were adopted to measure the customers' perceptions of value dimensions, credibility, image, trust and repurchase intentions in the OTC herbal market in Cape Coast. This type of questionnaire was adopted with the view to generating data that allows for statistical analysis and better explanation of the findings (Creswell, 2014). The scale items were borrowed from previous studies. The scale items of brand credibility were taken from Erdem and Swait (2004), value dimensions were from Sweeney and Soutar (2001), brand trust from Chaudhuri and Holdbrook (2001), brand image from Yoo, Donthu, and Lee (2000) and Gil, Andrés, and Salinas (2007), and repurchase intention from Zeithaml et al., (1996) and Zhang et al. (2020). The survey questionnaires were distributed to the respondents after shopping via a systematic sampling procedure. Thus, the first customer was randomly selected and afterwards, a third of every customer was invited to participate in the study. This sampling strategy was employed because it creates an avenue to pick respondents without prior information about them in the sample frame (Malhotra, Nunan, \& Birks, 2017).

A total of 230 questionnaires were given out, but 208 were usable due to invalid responses.

\subsection{Sample Characteristics}

The sample characteristics in Table 1 demonstrate that a large percentage of the samples were male, between the age of 26 to 35 , and had completed senior high school. In other words, 104 (50.7\%) were male, 81 (39.1\%) were between 26 and 35 years, and 74 (36.5\%) had completed senior high school. 
Table 1. Results of sample characteristics.

\begin{tabular}{|c|c|c|c|}
\hline Variables & Frequency & Valid Percent (\%) & Cumulative Percent (\%) \\
\hline \multicolumn{4}{|c|}{ Gender } \\
\hline Male & 104 & 50.7 & 50.7 \\
\hline Female & 101 & 49.3 & 100.0 \\
\hline Total & 205 & 100.0 & \\
\hline \multicolumn{4}{|c|}{ Age (Years) } \\
\hline $18-25$ years & 47 & 22.7 & 22.7 \\
\hline $26-35$ years & 81 & 39.1 & 61.8 \\
\hline 36 - 45 years & 40 & 19.3 & 81.2 \\
\hline $46-60$ years & 32 & 15.5 & 96.6 \\
\hline More than 60 years & 7 & 3.4 & 100.0 \\
\hline Total & 207 & 100.0 & \\
\hline \multicolumn{4}{|c|}{ Level of Education } \\
\hline JHS & 42 & 20.7 & 20.7 \\
\hline SHS & 74 & 36.5 & 57.1 \\
\hline Diploma & 30 & 14.8 & 71.9 \\
\hline HND & 21 & 10.3 & 82.3 \\
\hline Bachelor & 22 & 10.8 & 93.1 \\
\hline Master & 4 & 2.0 & 95.1 \\
\hline $\mathrm{PhD}$ & 1 & .5 & 95.6 \\
\hline Others & 9 & 4.4 & 100.0 \\
\hline Total & 203 & 100.0 & \\
\hline
\end{tabular}

Source: Field data.

\subsection{Data Analysis and Results}

The statistical procedures used to address the purpose of the study were exploratory factor analysis (EFA) and structural equation model (SEM), using SPSS Amos 20 software.

\subsection{Exploratory Factor Analysis}

The purpose of the EFA was to ascertain how well the multiple scale items converge on their respective constructs in the study. A total of 33 indicators were subjected to the EFA using the principal axis factoring extraction method and an Oblimin rotation procedure. Table 2 shows that the Kaiser-Meyer-Olkin (KMO) Measure of Sampling Adequacy is .862 and Bartlett's Test of Sphericity is significant at $p<.05$, suggesting that the EFA is acceptable (Hair, Black, Babin, \& Anderson, 2014; Pallant, 2013). Furthermore, the pattern matrix yielded an eight-factor 
Table 2. Result of exploratory factor analysis.

\begin{tabular}{|c|c|c|c|c|c|c|c|c|c|}
\hline & \multirow{2}{*}{ Scale Items } & \multicolumn{8}{|c|}{ Factor } \\
\hline & & 1 & 2 & 3 & 4 & 5 & 6 & 7 & 8 \\
\hline PEV3 & $\mathrm{X}$ gives me a sense of joy & .773 & & & & & & & \\
\hline PEV2 & $\mathrm{X}$ gives me pleasure & .649 & & & & & & & \\
\hline PEV1 & $\mathrm{X}$ makes me feel good & .539 & & & & & & & \\
\hline PEV4 & $\mathrm{X}$ makes me want to buy it. & .506 & & & & & & & \\
\hline PPV2 & $\mathrm{X}$ offers value for money & & .951 & & & & & & \\
\hline PPV4 & $\mathrm{X}$ is economical & & .876 & & & & & & \\
\hline PPV1 & $\mathrm{X}$ is reasonably priced & & .828 & & & & & & \\
\hline PPV3 & $\mathrm{X}$ is worth the price & & .751 & & & & & & \\
\hline $\mathrm{BC} 2$ & $\mathrm{X}$ delivers what it promises & & & .739 & & & & & \\
\hline BC4 & X`s product claims are believable & & & .734 & & & & & \\
\hline $\mathrm{BC} 1$ & $\mathrm{X}$ has a name you can trust & & & .686 & & & & & \\
\hline BC5 & $\begin{array}{l}\text { Over time, my experiences with } \mathrm{X} \text { had } \\
\text { led me to expect it to keep its promises. }\end{array}$ & & & .673 & & & & & \\
\hline $\mathrm{BC} 3$ & $\begin{array}{l}\mathrm{X} \text { has the ability to deliver what it } \\
\text { promises }\end{array}$ & & & .620 & & & & & \\
\hline PFV1 & $\mathrm{X}$ has consistent quality & & & & .831 & & & & \\
\hline PFV3 & $\mathrm{X}$ is well-made & & & & .825 & & & & \\
\hline PFV2 & $\mathrm{X}$ performs consistently & & & & .805 & & & & \\
\hline PFV4 & $\mathrm{X}$ is very reliable & & & & .767 & & & & \\
\hline RPI2 & $\begin{array}{l}\text { I intend to keep buying more of } \mathrm{X} \text { in } \\
\text { the future }\end{array}$ & & & & & .732 & & & \\
\hline RPI3 & I will buy $\mathrm{X}$ the next time & & & & & .725 & & & \\
\hline RPI1 & $\begin{array}{l}\text { I would consider } \mathrm{X} \text { as my first choice } \\
\text { when buying herbal medicine }\end{array}$ & & & & & .698 & & & \\
\hline RPI4 & Overall, I buy X most often & & & & & .652 & & & \\
\hline PSV2 & $\mathrm{X}$ would give me social approval & & & & & & .798 & & \\
\hline PSV3 & $\begin{array}{l}\mathrm{X} \text { would improve the way people } \\
\text { think about me }\end{array}$ & & & & & & .635 & & \\
\hline PSV1 & $\mathrm{X}$ would help me feel acceptable & & & & & & .555 & & \\
\hline PSV4 & $\begin{array}{l}\mathrm{X} \text { would create a good relationship } \\
\text { between me and my friends }\end{array}$ & & & & & & .437 & & \\
\hline BT4 & This is an honest brand & & & & & & & .688 & \\
\hline BT2 & I rely on $\mathrm{X}$ to solve my problems & & & & & & & .682 & \\
\hline BT1 & I trust $\mathrm{X}$ & & & & & & & .676 & \\
\hline BT3 & $\mathrm{X}$ is safe & & & & & & & .634 & \\
\hline BI2 & $\begin{array}{l}\text { I can quickly recall the symbol or logo } \\
\text { of } X\end{array}$ & & & & & & & & .623 \\
\hline
\end{tabular}




\section{Continued}

\begin{tabular}{|c|c|c|c|c|c|c|c|c|c|}
\hline BI3 & I like the image of $\mathrm{X}$ in the marketplace & & & & & & & & .606 \\
\hline BI1 & $\mathrm{X}$ is different from its competing brands & & & & & & & & .412 \\
\hline & Coefficient Alpha & .857 & .925 & .853 & .909 & .851 & .791 & .851 & .734 \\
\hline & Eigenvalues & 10.54 & 3.33 & 2.54 & 1.93 & 1.65 & 1.39 & 1.17 & 1.01 \\
\hline & Percentage of Variance Explained & 31.93 & 10.10 & 7.71 & 5.86 & 5.01 & 4.22 & 3.55 & 3.06 \\
\hline \multicolumn{10}{|c|}{ Percentage of Total Variance Explained $=71.44$} \\
\hline
\end{tabular}

Note: $\mathrm{X}$ is the focal brand.

structure. Emotional value is factor 1, price value is factor 2, brand credibility is factor 3, quality/performance is factor 4 , repurchase intention is factor 5 , social value is factor 6 , brand trust is factor 7 , and brand image is factor 8 . The number of indicators that loaded on their respective factors was 32 because one of them cross-loaded with another factor and was eliminated (Floyd \& Widaman, 1995). More so, the eight factors' eigenvalues exceeded 1.0 and explained $71.44 \%$ of the cumulative variance of the analysis.

More so, after the EFA, the scale items' internal consistency reliability was analysed to remove those with poor inter-item correlations. The findings show that all the factors had coefficients above .70, ranging from .734 to .925 , showing good internal consistency reliability (Tavakol \& Dennick, 2011).

\section{Structural Equation Modelling}

The SEM was used to evaluate hypothesised relationships in the study. This multivariate statistical tool was chosen because it is capable of evaluating a number of individual multiple regressions at the same time. The SEM also creates an opportunity to modify the model, provides the model's overall fit, and residual errors attached to each scale item (Hair et al., 2014; Bryne, 2016). The SEM was conducted in two stages as recommended by Bryne (2016). In this regard, the measurement model was analysed before the structural model.

\subsection{Measurement Model}

The measurement model was carried out to validate the findings of the EFA, and to ascertain the construct reliability and validity. Thirty-two (32) scale items produced from the EFA were used for the measurement model. To check convergent validity, standardised regression estimates of scale items less than .50 were removed from the model (Hair et al., 2014). The results in Figure 2 show that the standardised regression weights of all the constructs were statistically significant at $p<.001$, and varied between .51 and .850 .

Moreover, the model fit indexes proved satisfactory except for the Chi-square statistic (CMIN $=433.349, \mathrm{DF}=216, p<.001)$ because of its sensitivity to sample 


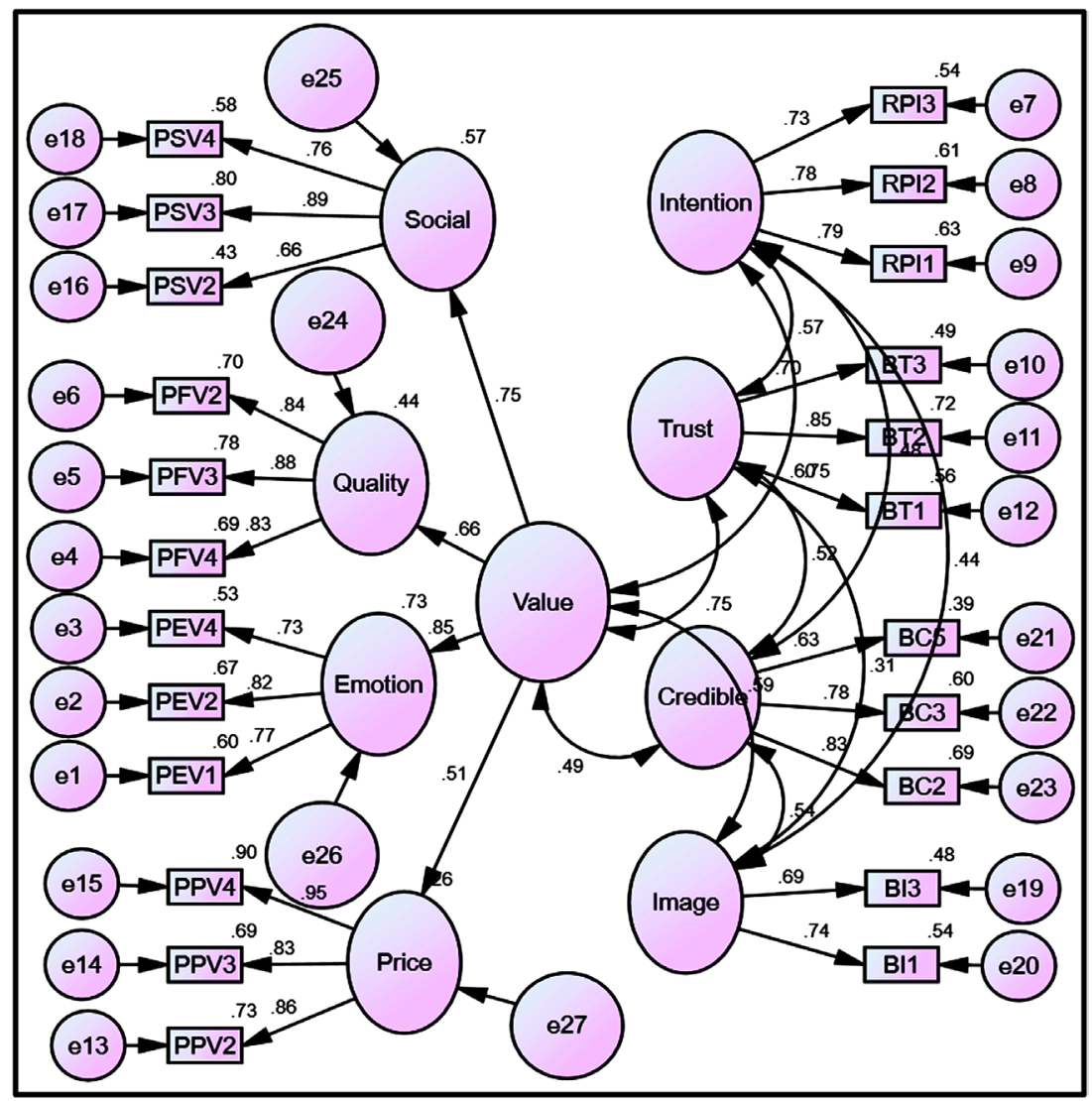

Figure 2. Results of the measurement model.

size. The Normed Chi-Square statistic $(\mathrm{CMIN} / \mathrm{DF})=2.006$; Goodness-of-Fit Index $(\mathrm{GFI})=.859$; Root Mean Residual $(\mathrm{RMR})=.066$; Root Mean Square Error of Approximation (RMSEA) $=.067$; Comparative Fit Index $(\mathrm{CFI})=.920$; Tucker-Lewis Index $(\mathrm{TLI})=.907$; Incremental Fit Index (IFI) = .921, suggested satisfactory model fit (Hu \& Bentler, 1999; Kline, 2015; Hair et al., 2014).

\subsection{Psychometric Measures}

The psychometric measures examined in this paper were construct reliability and validity. The construct validity was determined by using convergence validity and discriminant validity (Hair et al., 2014). The results in Table 3 indicate that the constructs have convergence validity because their average variance extracted (AVEs) are within the limit of .50, which ranged from .500 to .590 (Fornell \& Lacker, 1981). Again, the findings reveal that the square roots of the AVEs of the constructs were above the squared inter-correlations, indicating good discriminant validity (Bagozzi \& Yi, 1988; Hair et al., 2014). Likewise, the results of the composite reliability suggest that all the estimates fall within the limit of .70, confirming construct reliability (Fornell \& Larcker, 1981; Bagozzi \& Yi, 1988). These outcomes demonstrate that the latent constructs are reliable and valid for the analysis of the path model. 
Table 3. Results of psychometric measures.

\begin{tabular}{cccccccc}
\hline Latent Constructs & CR & AVEs & PV & RI & BT & BC & BI \\
\hline Perceived Value (PV) & .793 & .500 & $.707^{* *}$ & & & & \\
Repurchase Intentions (RI) & .811 & .589 & .355 & $.767^{* *}$ & & & \\
Brand Trust (BT) & .810 & .590 & .559 & .320 & $.768^{* *}$ & & \\
Brand Credibility (BC) & .791 & .561 & .236 & .231 & .265 & $.749^{* *}$ & \\
Brand Image (BI) & .675 & .510 & .346 & .190 & .095 & .292 & $.714^{* *}$ \\
\hline
\end{tabular}

Notes: $\mathrm{CR}=$ Composite Reliability; ${ }^{* *}=$ Square root of AVEs; off-diagonal estimates measure the squared inter-construct correlations.

\subsection{Structural Model}

The structural model was employed to assess the hypothesised relationships posited in the research. As stated earlier, brand credibility, image and trust are the predictor variables, perceived value is an intervening variable, whereas repurchase intention is the outcome variable. The Chi-square test $(\mathrm{CMIN}=490.477$, $\mathrm{DF}=2.229, p=.000)$ was statistically significant at $p<.001$, and hence, the model was rejected. However, the CMIN/DF $=2.229$; GFI $=.850$; TLI $=.886$; IFI $=.902$; CFI $=.901 ;$ RMSEA $=.074$ are quite admissible. The results in Figure 3 show that emotional value $(\beta=.825, \mathrm{t}=5.723)$, quality $(\beta=.655, \mathrm{t}=5.448)$, social

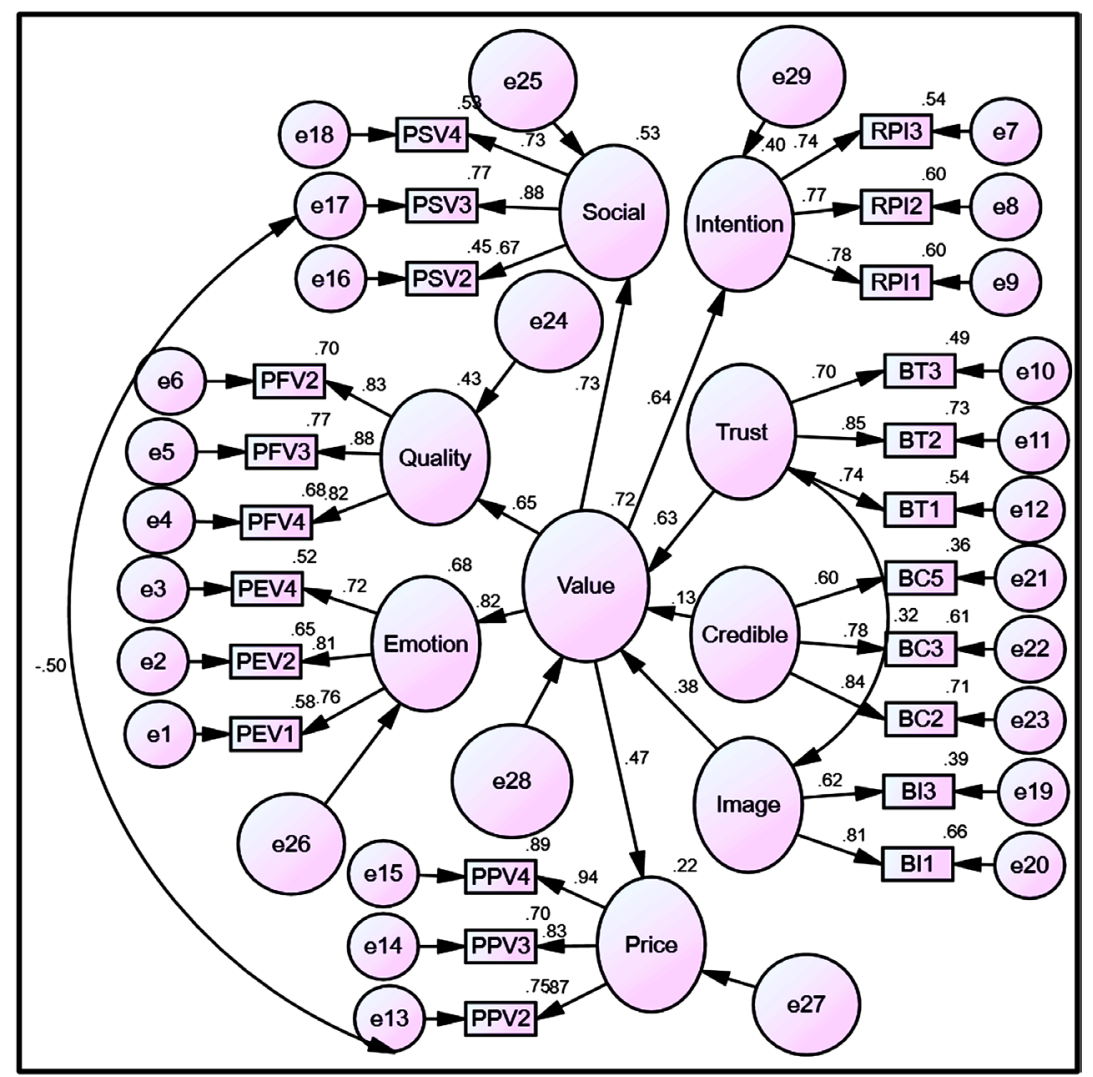

Figure 3. Results of structural model. 
value $(\beta=.728, \mathrm{t}=5.249)$ and price value $(\beta=.468, \mathrm{t}=5.249)$ have direct effect on perceived value at significance level of $p<.001$. Furthermore, the results point out that brand credibility $(\beta=.130, \mathrm{t}=2.028)$ has a positive effect on perceived value at $p<.05$, supporting $H 1$. Moreover, the results indicate that brand trust $(\beta=.635, \mathrm{t}=5.967)$ and image $(\beta=.380, \mathrm{t}=4.210)$ are directly related to perceived value at $p<.001$, confirming $H 2$ and $H 3$ respectively. Lastly, the findings demonstrate that the perceived value $(\beta=.635, \mathrm{t}=5.879)$ has a significant effect on repurchase intentions at the significance level of $p<.001$.

\section{Discussion and Implications}

The goal of this research was to identify the importance of brand credibility, trust, image and perceived value dimensions to repurchase intentions in the OTC herbal market.

The results demonstrate that perceived quality/performance, price, emotional and social value are directly related to perceived value in the OTC market. This outcome concurs with the existing literature (Sweeney \& Soutar, 2001), which indicates that perceived quality, price, emotional and social value are the key elements of perceived value. This suggests that the customers' perceived value can be increased by considering perceived quality, monetary value, emotional value and social value in the OTC herbal market. Creating value over and above the competition to satisfy the target market is regarded as one of the surest ways of gaining a sustainable advantage in the market.

This study found that perceived value has a direct impact on customers' repurchase intentions in the OTC herbal market. This result is consistent with past studies (De Toni et al., 2018; Huang et al., 2019), which established that perceived value has a direct influence on customers' repurchase intentions. This implies that enriching and harnessing perceived quality, social value, emotional value and price value can generate customers' repurchase intentions in the OTC market.

The findings of the study further demonstrate that brand credibility has a significant influence on the perceived value, i.e. emotional value, performance/ quality, price value and social value in the OTC herbal market. The results are consistent with prior studies (Cuong, 2020; Baek \& King, 2011), which suggested that credible brands enhance the perceived value of a product. This outcome is contrary to the findings of earlier authors (Ok, Choi \& Hyun, 2011; Baek \& King, 2011), which revealed that perceived value contributes to strengthening a brand's credibility. The study's result implies that an increased brand's credibility directly influences its perceived performance, emotional, monetary, and social value in the OTC herbal market.

Consistent with previous studies (Sirdeshmukh et al., 2002; Carnevale et al., 2018), the findings of the current research show that brand trust positively affects the perceived value of brands in the OTC herbal market. However, this re- 
sult contrasts sharply with prior studies (Prameka, Do \& Rofiq, 2016; Erciş, Unal, Candan \& Yildirim, 2012), which demonstrated that perceived value positively impacts customers' brand trust. The result, therefore, suggests that brands that can be trusted significantly strengthen their perceived performance, monetary, emotional and social value in the market. More so, brand trust exerts a stronger influence on perceived value compared to image and credibility in the OTC herbal market. Accordingly, building trusted brands can mitigate the perceived risks surrounding the consumption of herbal therapies and, thus, will enrich their perceived value. This will, in turn, enhance the customers' repurchase intentions in the OTC herbal market.

Finally, the study established that brand image has a significant direct influence on perceived value in the OTC herbal market. This outcome is similar to the earlier studies (Pham \& Nguyen, 2019; Lien et al., 2015), which report that favourable brand image directly affects the perceived value. However, this result differs from the study of prior authors (Chung, Yu, Kim \& Shin, 2015; Yan, 2019), who found that enhanced perceived value enhances the image of brands. Thus, the study's outcome demonstrates that a favourable and strong image contributes to strengthening the perceived performance, monetary, emotional and social value of the brands in the OTC herbal market.

\section{Recommendations}

Based on the findings of the research, the following recommendations are made which have strategic importance to the management of the OTC herbal medicine companies in Ghana.

The research found that perceived quality/performance, price, emotional and social value positively influence perceived value in the OTC market. It is recommended that the managers should consider the perceived quality, monetary value, emotional value and social value in totality to enhance the customers' perceived value in the OTC herbal market.

Besides, the study revealed that perceived value has a direct impact on customers' repurchase intentions in the OTC herbal market. Hence, the managers in the OTC herbal industry should develop and exploit the perceived quality, social, emotional and price value of their brands to reap substantial gains from the behavioural actions of their customers' convictions to repeatedly purchase from them.

Again, the study points out that brand credibility has a significant impact on the perceived value in the OTC herbal market. Consequently, it is recommended that the managers need to increase their brands' credibility to strengthen their perceived quality, social value, emotional value and monetary value in the OTC herbal market. The research also established that brand trust has a positive influence on perceived value in the OTC herbal market. More importantly, brand trust exerts a stronger influence on perceived value compared to image and credibility in the OTC herbal market. Therefore, recognising the important role of 
brand trust in enhancing perceived value, the managers of OTC herbal firms should create and harness brand trust to increase the perceived value in the industry.

Lastly, the study established that brand image has a significant direct influence on perceived value in the OTC herbal market. In this regard, any effort made by management to build a favourable image of the brands will increase their perceived quality, monetary value, social value and emotional value, which will, in turn, support the customers' repurchase intentions in the OTC herbal market.

\section{Conclusion}

The main objective of the study was to determine the importance of brand credibility, trust, image and perceived value dimensions to repurchase intentions in the OTC herbal market. The research established that the value dimensions (quality, price, emotional and social value) directly influence the perceived value of brands in the OTC herbal market. Although some authors are of the view that perceived value is a single-dimensional construct, this study upholds the position of other authors that perceived value is a multi-dimensional construct. Furthermore, the study revealed that brand credibility, trust and image positively affect the perceived value of herbal medicines sold in the OTC market. Thus, high brand credibility, favourable brand image and strong brand trust exert a strong influence on the perceived quality, price, the emotional and social value of the brands in the OTC herbal market. This study also established that brand credibility, image and trust are important antecedents of the value dimensions in the OTC herbal market. Finally, the study found that perceived value directly impacts the customers' repurchase intentions in the OTC herbal market. That is, the customers' repurchase intentions are positively affected by the perceived quality, price, the emotional and social value of the brands retailed in the OTC herbal market. This research, therefore, confirms that brand credibility, trust, image and value dimensions are essential sources for increasing customers' repurchase intentions in the OTC herbal market.

\section{Conflicts of Interest}

The authors declare no conflicts of interest regarding the publication of this paper.

\section{References}

Aaker, D. A. (1991). Managing Brand Equity: Capitalising on the Value of Brand Name. The Free Press.

Baek, T. H., \& King, K. W. (2011). Exploring the Consequences of Brand Credibility in Service. Journal of Services Marketing, 25, 260-272. https://doi.org/10.1108/08876041111143096

Bagozzi, R. P., \& Yi, Y. (1988). On the Evaluating Structural Equation Models. Journal of Academy of Marketing Research, 16, 74-94. https://doi.org/10.1007/BF02723327 
Bryne, B. M. (2016). Structural Equation Modelling with AMOS: Basic Concepts, Applications and Programming (3rd ed.). Routledge. https://doi.org/10.4324/9781315757421

Carnevale, M., Loureiro, Y. K., \& Kabadayi, S. (2018). Customer Value Creation for Risky Products: The Role of Brand Trust and Trusting Beliefs. Journal of Creating Value, 4, 1-21. https://doi.org/10.1177\%2F2394964317752731

Chaudhuri, A., \& Holbrook, M. B. (2001). The Chain of Effects from Brand Trust and Brand Affect to Brand Performance: The Role of Brand Loyalty. Journal of Marketing, 65, 81-93. https://doi.org/10.1509\%2Fjmkg.65.2.81.18255

Chen, C.-F., \& Chen, F.-S. (2010). Experience Quality, Perceived Value, Satisfaction and Behavioural Intentions for Heritage Tourists. Tourism Management, 31, 29-35.

https://doi.org/10.1016/j.tourman.2009.02.008

Chuah, H. W., Marimuthu, M., \& Ramayah, T. (2014). The Effect of Perceived Value on Loyalty of Generation Y Mobile Internet Subscribers: A Proposed Conceptual Framework. Procedia-Social and Behavioural Sciences, 130, 532-541. https://doi.org/10.1016/j.sbspro.2014.04.062

Chung, K., Yu, J., Kim, W., \& Shin, J. (2015). The Effect of Perceived Value on Customer Loyalty in a Low-Priced Cosmetic Brand of South Korea: The Moderating Effect of Gender. Ibusiness, 40-44.

Creswell, J. W. (2014). Research Design: Qualitative, Quantitative, and Mixed Methods Approaches (4th ed.). SAGE Publications

Cronin Jr., J. J., Brady, M. K., \& Hutt, G. T. M. (2000). Assessing the Effects of Quality, Value, and Customer Satisfaction on Consumer Behavioural Intentions in Service Environments. Journal of Retailing, 76, 193-218.

https://doi.org/10.1016/S0022-4359(00)00028-2

Cuong, D. T. (2020). The Impact of Brand Credibility and Perceived Value on Customer Satisfaction and Repurchase Intentions at Fashion Market. Journal of Advance Research in Dynamic \& Control System, 12, 691-700.

https://doi.org/10.5373/JARDCS/V12SP3/20201308

De Toni, D., Eberle, L., Larentis, F., \& Milan, G. S. (2018). Antecedent of Perceived Value and Repurchase Intention of Organic Food. Journal of Food Product Marketing, 24, 456-475. https://doi.org/10.1080/10454446.2017.1314231

Demirgüneş, B. K. (2015). Relative Importance of Perceived Value, Satisfaction and Perceived Risk on Willingness to Pay More. International Review Management and Marketing, 5, 211-220.

Erdem, T., \& Swait, J. (1998). Brand Equity as a Signaling Phenomenon. Journal of Con sumer Psychology, 7, 131-157. https://doi.org/10.1207/s15327663jcp0702 02

Erdem, T., \& Swait, J. (2004). Brand Credibility, Brand Consideration, and Brand Choice. Journal of Consumer Research, 13, 191-198. https://doi.org/10.1086/383434

Ericş, A., Unal, S., Candan, F. B., \& Yildirim, H. (2012). The Effect of Brand Satisfaction, Trust, and Brand Commitment on Loyalty and Repurchase Intentions. Procedia-Social and Behavioural Sciences, 58, 1395-1401. https://doi.org/10.1016/j.sbspro.2012.09.1124

Essegbey, G. O., Awuni, S., Essegbey, I. T., Akuffobea, M., \& Mica, B. (2014). Country Study on Innovations, Intellectual Property and Informal Economy: Traditional Medicines in Ghana (13th ed.). World International Property Organization.

Floyd, F. J., \& Widaman, K. F. (1995). Factor Analysis in the Development and Refinement of Clinical Assessment Instrument. Psychological Assessment, 7, 286-299.

https://doi.apa.org/doi/10.1037/1040-3590.7.3.286 
Fornell, C., \& Larcker, D. F. (1981). Evaluating Structural Equation Models with Unob servable Variables and Measurement Error. Journal of Marketing Research, 18, 39-50. https://doi.org/10.1177\%2F002224378101800104

Gil, R. B., Andrés, E. F., \& Salinas, E. M. (2007). Family as a Source of Customer-Based Brand Equity. Journal of Product \& Brand Management, 16, 188-199. https://doi.org/10.1108/10610420710751564

Hair Jr., J. H., Black, W. C., Babin, B. J., \& Anderson, R. E. (2014). Multivariate Data Analysis (7th ed.). Pearson Education.

Hellier, P. K., Geursen, G. M, Carr, R. A., \& Richard, J. A. (2003). Customer Repurchase Intentions: A General Structural Equation Model. European Journal Marketing, 37, 1762-1800. https://doi.org/10.1108/03090560310495456

Hu, L., \& Bentler, P. M. (1999). Cut-Off Criteria for Fit Indexes in Covariance Structure Analysis: Conventional Criteria versus New Alternatives. Structural Equation Modelling: Multidisciplinary Journal, 6, 1-55. https://doi.org/10.1080/10705519909540118

Huang, L.-C., Gao, M., \& Hsu, P.-F. (2019). A Study on the Effect of Brand Image on Perceived Value and Repurchase Intentions in Ecotourism Industry. Ekoloji, 28, 283-287.

Kantamneni, S. P., \& Coulson, K. R. (1996). Measuring Perceived Value: Scale Develop ment and Research, Findings from a Consumer Survey. Journal of Marketing Management, 6, 72-86.

Keller, K. L. (1993). Conceptualizing, Measuring and Managing Customer-Based Brand Equity. Journal of Marketing, 57, 1-22. https://doi.org/10.1177\%2F002224299305700101

Keller, K. L. (2013). Strategic Brand Management: Building Measuring, and Managing Brand Equity, Global Edition (4th ed.). Pearson Education.

Kline, R. B. (2015). Principles and Practice of Structural Equation Modelling (2nd ed.). Guilford Press.

Kotler, P., \& Keller, K. L. (2012). Marketing Management (14th ed.). Pearson Education Inc.

Krejcie, R. V., \& Morgan, D. V. (1970). Determining Sample Size for Research Activities. Education and Psychological Measurement, 30, 607-610. https://doi.org/10.1177\%2F001316447003000308

Lien, C.-H., Wen, M.-J., Huang, L.-C., \& Wu, K. L. (2015). Online Hotel Booking: The Effects of Brand Image, Price, Trust and Value on Purchase Intentions. Asian Pacific Management Review, 20, 210-218. https://doi.org/10.1016/j.apmrv.2015.03.005

Malhotra, N. K., Nunan, D., \& Birks, D. F. (2017). Marketing Research: An Applied Ap proach (5th ed.). Pearson Education.

Miles, M. B., Huberman, A. M., \& Saldaña, J. (2014). Qualitative Data Analysis: A Meth ods Sourcebook (3rd ed.). SAGE Publication.

Morgan, R. M., \& Hunt, S. D. (1994). The Commitment-Trust Theory of Relationship Marketing. Journal of Marketing, 58, 20-38. https://doi.org/10.1177\%2F002224299405800302

Ok, C., Choi, Y. G., \& Hyun, S. S. (2011). Roles of Brand Value Perceptions in the Development of Brand Credibility and Brand Prestige. International CHRIE ConferenceRefereedTrack.13. https://scholarworks.umass.edu/refereed/ICHRIE 2011/Wednesday/13

Oliver, R. L. (2010). Satisfaction: A Behavioural Perspective on Consumer (2nd ed.). Routledge. 
Pallant, J. (2013). SPSS Survival Manual: A Step-by-Step Guide to Data Analysis Using $I B M$ SPSS (5th ed.). McGraw-Hill Education.

Petrick, J. F. (2002) Development of a Multi-Dimensional Scale for Measuring the Perceived Value of Service. Journal of Leisure Research, 34, 119-134. https://doi.org/10.1080/00222216.2002.11949965

Pham, H., \& Nguyen, T. (2019). The Effect of Website Quality on Repurchase Intentions with Mediation of Perceived Value: The Case Study of Online Travel Agencies in Vietnam. Journal of Global Business Insights, 4, 78-91. https://doi.org/10.5038/2640-6489.4.1.1041

Premeka, A. S., Do, B.-R., \& Rofig, A. (2016). How Brand Trust Is Influenced by Perceived Value and Service Quality: Mediated by Hotel Customer Satisfaction. Asian Pacific Management \& Business Application, 5, 73-88.

https://doi.org/10.21776/ub.apmba.2016.005.02.2

Punniyamoorthy, M., \& Raj, M. P. M (2007). An Empirical Model for Brand Loyalty Measurement. Journal of Targeting, Measurement and Analysis for Marketing, 15, 222233. https://doi.org/10.1057/palgrave.jt.5750044

Rambocas, M., Kirpalani, V. M., \& Simms, E. (2018). Brand Equity and Customer Behavioral Intentions: A Mediated Moderated Model. International Journal of Bank Marketing, 36, 19-40. https://doi.org/10.1108/IJBM-09-2016-0139

Ryu, K., Han, H., \& Kim, T. H. (2008). The Relationships among Overall Quick-causal Restaurant Image, Perceived Value, Customer Satisfaction, and Behavioral Intentions. International Journal of Hospitality Management, 27, 459-469.

https://doi.org/10.1016/j.ijhm.2007.11.001

Saha, G. C., \& Theingi, T. (2009). Service Quality, Satisfaction, and Behavioral Intentions; A Study of Low-Cost Airline Carriers in Thailand. Managing Service Quality, 19, 350372. https://doi.org/10.1108/09604520910955348

Sánchez-Fernández, R., \& Iniesta-Bonillo, M. A. (2007). The Concept of Perceived Value: A systematic Review of the Research. Marketing Theory, 7, 427-451. https://doi.org/10.1177\%2F1470593107083165

Sheth, J. N., Newman, B. I., \& Gross, B. L. (1991). Why We Buy What We Buy: A Theory of Consumption Values. Journal of Business Research, 22, 159-170. https://doi.org/10.1016/0148-2963(91)90050-8

Sirdeshmukh, D., Singh, J., \& Sabol, B. (2002). Consumer Trust, Value and Loyalty in Relational Exchanges. Journal of Marketing, 66, 15-37. https://doi.org/10.1509\%2Fjmkg.66.1.15.18449

Sweeney, J. C., \& Soutar, G. N. (2001). Consumer Perceived Value: The Development of a Multiple Item Scale. Journal of Retailing, 77, 203-220.

https://doi.org/10.1016/S0022-4359(01)00041-0

Tavakol, M., \& Dennick, R. (2011). Making Sense of Cronbach's Alpha. International Journal of Medical Education, 2, 53-55. https://doi.org/10.5116/ijme.4dfb.8dfd

UNDP (2007). Ghana Human Development Report 2007: Towards a More Inclusive Society. United Nations Development Programme, Ghana Office, 42.

WHO (World Health Organization) (1998). Guidelines for Appropriate Use of Herbal Medicines. Western Pacific Series No. 28. WHO Regional Publications

WHO (World Health Organization) (2008). Traditional Medicine. Fact Sheet No.134.

WHO (World Health Organization) (2011). Traditional Medicines, Global Situation, Issues, and Challenges. In The World Medicines Situation (3rd ed., p. 14). World Health 
Organization.

Yague-Guillen, M. J., Munuera-Alemán, J. L., \& Delgado-Ballester, E. (2003). Develop ment and Validation of a Brand Trust Scale. International Journal of Market Research, 45, 1-18. https://doi.org/10.1177\%2F147078530304500103

Yan, B. (2019). Research on the Influence of Customer Perceived Value and Brand Equity. American Journal of Industrial and Business Management, 9, 609-626. https://doi.org/10.4236/ajibm.2019.93042

Yoo, B., Donthu, N., \& Lee, S. (2000). An Examination of Selected Marketing Mix Ele ments and Brand Equity. Journal of the Academy of Marketing Science, 28, Article No. 195. https://doi.org/10.1177/0092070300282002

Zeithaml, V. A. (1988). Consumer Perceptions of Price, Quality, and Value: A Means-End Model and Synthesis of Evidence. Journal of Marketing, 52, 2-22. https://doi.org/10.1177\%2F002224298805200302

Zeithaml, V. A., Berry, L. L., \& Parasuraman, A. (1996). The Behavioural Consequences of Service Quality. Journal of Marketing, 60, 31-46. https://doi.org/10.1177\%2F002224299606000203

Zhang, S., Peng, M. Y-P, Peng, Y., Zhang, Y., Ren, G., \& Chen, C.-C. (2020). Expressive Brand Relationship, Brand Love, and Brand Loyalty for Tablet P.Cs: Building Sustainable Brand. Frontiers in Psychology, 11, Article No. 763.

https://doi.org/10.3389/fpsyg.2020.00763 